\title{
RARE ANIMALS AT WOBURN \\ THE PRESERVATION WORK OF THE LATE DUKE OF BEDFORD
}

\section{By G. Kenneth Whitehead}

With the tragic death, through a shooting accident, of the 12th Duke of Bedford on the 9th October, 1953, the Fauna Preservation Society has lost one of its most able members, for not only was he keenly interested in anything connected with the preservation of wild life, but at Woburn he was also actively engaged in preserving certain species of ruminants that might otherwise have been lost to mankind for ever.

The late Duke's father, himself a keen naturalist, started about 1895 the Woburn collection and during the next twenty years he collected together as great a number of species of wild ruminants and birds as probably existed anywhere else in the world. Fortunately, the Duke inherited his father's keen interest in natural history, and when, in 1940, he succeeded to the dukedom, he was more than qualified to take over the care of this unique collection.

The late Duke was a purist and one of the first tasks he set about doing was to weed out the various hybrids that had been allowed to remain in the park to the detriment of the pure-bred animals. He also perceived the folly of trying to retain certain species that were obviously unsuited for life in an open English park. At the present time eleven different species of deer are preserved in the park and these include the greatest zoological treasure in the whole of the Woburn collection-the herd of Père David's deer-for apart from a few animals recently sent from Woburn to Whipsnade, America and Australia, this is the only herd in the world. Of almost equal interest is the small herd of wisent, or European bison, for there is little doubt that had the war in Europe been much prolonged, the Woburn animals might well have been the sole surviving members of this breed. As it was, only ninety-seven pure bred wisent could be accounted for in Europe at the end of 1946 .

Here, too, the last surviving remnants of the old Chartley herd of white cattle have found sanctuary, whilst in the woods and on the ponds many species of pheasants and waterfowl, some rare and some not so rare, abound.

The Père David's deer (Elaphurus davidianus) which originally came from the Honan district of China, takes its present name 


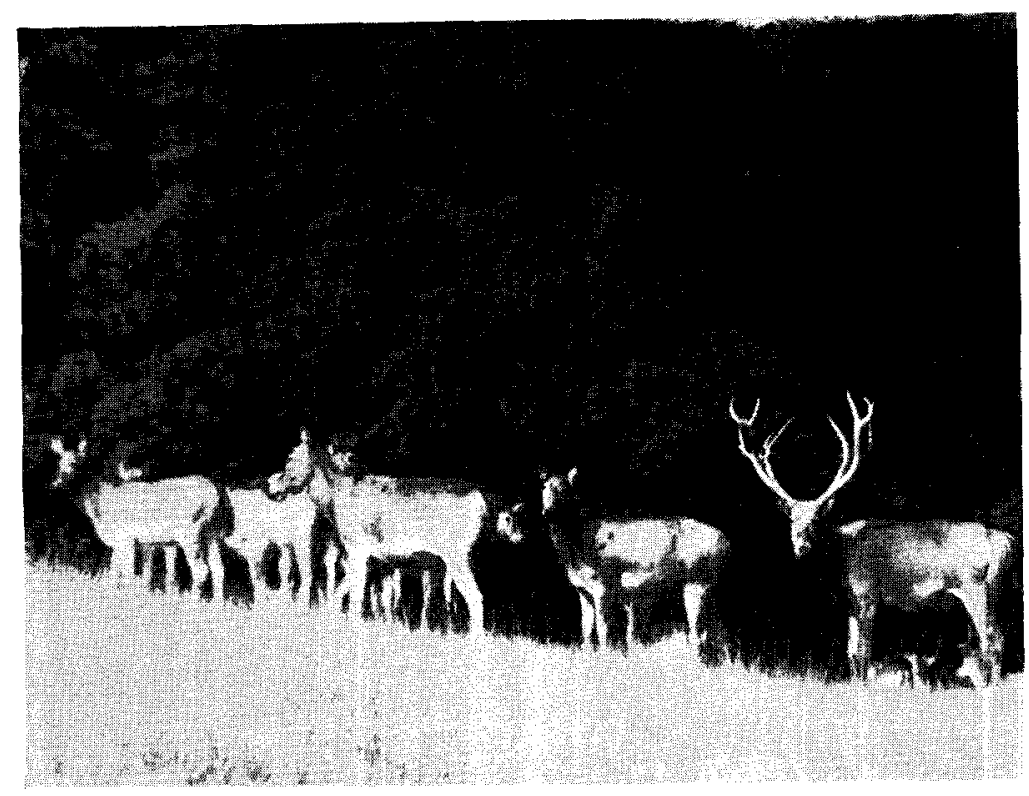

PNRE DAVIDS DEER.

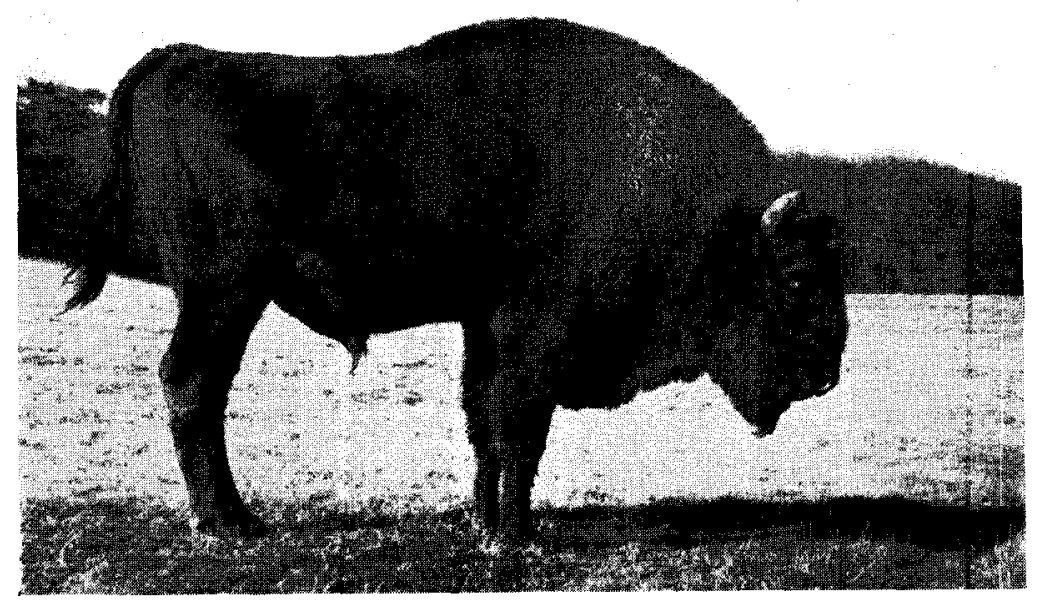

Photographs_by G. Kenneih Whitehcad EUROPEAN BISON. 
from the French missionary and traveller Père Armand David who, one Scptember day in 1865, first discovered the deer in the Imperial Hunting Park of Peking, known as Nan Hai-tze or South Lake. Its native name would appear to have been mi-lou, Sen-pou-siang, or Ssu pu hsiang.

Anxious to secure some specimens for the Paris natural history museum, Père David accordingly made arrangements with some of the park keepers to obtain for him the hides and bones of a pair of deer for which he would recompense them with twenty taels. It was, apparently, not without some difficulty and danger that the transaction was completed, for not only did each party mistrust the other, but it was strictly against orders for specimens to leave the park. However, one dark January night in 1866 the specimens were duly handed over the wall to Père David and the keepers received their reward. Shortly after this, M. Henri de Bellonet, Chargé d'Affaires of the French Legation in Peking, managed to secure a living pair, but the male did not survive long.

The discovery of this new species of deer, quite naturally, aroused the interest of the Zoological Society of London, and through the good offices of M. de Bellonet, a pair was placed at the disposal of the Society. Unfortunately, both died before reaching London. Eventually, on 2nd August, 1869, after several other unsuccessful attempts, a pair of deer reached London alive, but within twelve months both had died, leaving no progeny.

During the next ten years a few more specimens reached zoos in Paris and Berlin, but it was not until 1883 that another pair was received in London from a Paris menagerie. Once again, however, both animals died without leaving any progeny, the hind on 23rd June, 1885, and the stag on 28th June, 1891.

Then in 1894 tragedy descended upon the Nan Hai-tze herd which had been carefully preserved for the sport of the Chinese Court. A flood from the river Hun-Lo, which flows through the park, breached the wall in several places, and through the gaps thus made the bulk of the deer escaped, to be killed and devoured by the famine-stricken peasantry. It is believed, however, that a small remnant managed to survive and that these remained in the park until 1900. Then during the Boxer outbreak, the park was broken into by allied troops marching to the relief of the foreign legations in Peking, and the deer were either killed or captured, a few being shipped to Europe. This, however, was not quite the end of the Père David deer in China for Mr. A. de C. Sowerby reports that in 
1917 a pair, which had previously been preserved in one of the Manchu palaces' extensive grounds, was deposited in a zoo in Peking. Four years later they were dead. Thus so far as their native country was concerned the species was extinct.

However, in about 1898 a pair of young Père David's deer arrived at Woburn from a zoo in Paris, and in due course began to breed, first in a paddock and later in the open park. During the next few years other specimens were obtained from menageries in Paris, Antwerp and Berlin; of these the French and Belgian stock proved the most satisfactory, as the Berlin hinds were all sterile. When all the specimens in the European menageries had died off Woburn became the only home of the species. Since then, a few animals have been sent, not only to Whipsnade and Regent's Park, but to zoos in Australia and New York. Nevertheless, Woburn still remains the only place in the world where this animal can be seen living in conditions somewhat comparable to those enjoyed by the mi-lou which first attracted Père David's attention some eighty-nine years ago in Nan Hai-tze park. Moreover, it is probably the only mammal in the world which no living man has ever seen in an entirely wild state.

Its physical attributes are unique. For a deer it carries a remarkably long tail, and its hooves are wide and somewhat similar to those of a reindeer, which suggests they were designed for travel over snow. The antlers appear to be worn back-tofront, for instead of any forward-pointing tines, there is an extremely long back tine which appears to be of more use domestically than as a weapon of offence. It is particularly useful as a "back-scratcher", or for scooping up dollops of half-liquid mud, which the stag deposits on to the middle of its back so that it can run down its flanks in cooling streams. Occasionally, and particularly when given special feeding, the stag will grow two pairs of antlers during a year, which is a remarkable achievement for any deer. When this occurs the summer antlers are generally shed about October or November and a small pair, simple in structure, are grown and shed within a space of about three months; this allows the second full-growth antler to be complete by the rut which takes place in June and July. Gestation lasts about ten months-about six weeks longer than that of the red deer.

It will thus be seen that the Père David's deer undoubtedly is a unique animal. No other deer is quite like it, yet it carries the peculiar characteristics of many. In the interests of science alone every effort should be made to preserve this fine creature. 
In some respects the wisent, or European bison (Bison bonasus bonasus) "enjoys" a similar status to-day as do the Père David deer. It is now extinct as a wild animal in Europe where, as already mentioned, only about ninety-seven pure-bred animals remain in zoos or reserves specially set aside for their preservation-such as at Springe, in Germany, and Bialowies, in Poland. All pure-bred wisents are now entered in the stud book of the International Society for the Preservation of the Wisent.

The first trio of wisent - a bull and two cows-did not breed successfully but subsequent importation laid the foundation of the small herd of about twenty animals which still survive at Woburn. Unfortunately, between 1934-6 a tragic series of accidents, including lightning, destroyed all the pure-bred bulls. Since foot-and-mouth disease regulations prohibited the importation of a fresh bull, the late Duke's father, to continue the herd, was forced to use a bastard bull for breeding. This bull had, apparently, about one-sixteenth Russian domestic cow blood in his veins and although the percentage of alien blood was low, his calves were not accepted for registration in the pure-bred herd book. Since a limited number of wisent that are claimed to be of purer stock than those at Woburn are now being safely cared for in Europe, the preservation of the Woburn herd is in some respects not so vital. Nevertheless, the Woburn herd should be preserved at all costs, if only to ensure survival of the breed should accident, either by war or disease, overtake the herds in Europe. The events at Woburn between 1934-6 show only too vividly how accident can precipitate an apparently sound herd towards extinction. Moreover, I understand that shortly before his death the Duke was at last successful in obtaining a permit to import a pure-bred bull from Sweden, and this animal is now at Woburn. Presumably any progeny it may have will be acceptable for registration.

In these days of appallingly high taxation and penal death duties, it is not difficult to imagine the difficulties that must inevitably face the fulure managenent, in privale hands, of an estate like Woburn. Yet Woburn should be looked upon as a national heritage and as such, it would be an unforgiveable tragedy if demands by the exchequer should hinder the survival of such rare animals as the Père David's deer and wisent. One wonders if it was not a premonition of the recent tragedy that prompted the late Duke, less than three years ago, to write in the Proceedings of the Zoological Society: "Although there is at present no obvious threat to the survival of the Père David herd as far as natural causes are concerned, it is greatly to be 
feared that the follies of human leaders in various countries may yet bring about its extinction. Another war would certainly be fatal in its direct or indirect result, while death duties and over-taxation seem likely, before very long, to break up what is left of the fine collection of animals begun by my father."

Whatever, therefore, the future may bring, lovers of wild life throughout the world are extremely grateful for what the Dukes of Bedford have done to ensure the preservation of these two fine animals. It is for us to see that their fine work is preserved for future generations to see. Once destroyed, it will be gone for ever. 